\title{
Çocukluk Çağı Ailevi Akdeniz Ateşi Hastalarında Isı Şok Protein 90 Alfa ve Vitamin Düzeylerindeki Değişim
}

\author{
The Changes of Heat Shock Protein 90 Alpha and Vitamin \\ Levels in Pediatric Patients with Familial Mediterranean Fever
}

\author{
Bülent Ataş ${ }^{1}$, Serkan Kutlu ${ }^{2}$
}

\begin{abstract}
${ }^{1}$ Necmettin Erbakan Üniversitesi Meram Tıp Fakültesi Çocuk Sağlığı ve Hastalıkları Anabilim Dalı, Çocuk Nefrolojisi Bilim Dalı, Konya, Türkiye

${ }^{2}$ Necmettin Erbakan Üniversitesi Meram Tıp Fakültesi Çocuk Sağlığı ve Hastalıkları Anabilim Dalı, Konya, Türkiye
\end{abstract}

Yazışma Adresi: Bülent Ataş, Necmettin Erbakan Üniversitesi Meram Tıp Fakültesi Çocuk Sağlığı ve Hastalıkları AD, Çocuk Nefrolojisi BD, Konya, Turkey

e-mail: bulentatas@hotmail.com

Gelis Tarihi/Received: 20 Ocak 2020 Kabul Tarihi/Accepted: 9 Haziran 2020

\begin{abstract}
Öz
Amaç: Ailevi Akdeniz ateşi (AAA) tanılı hastalarımızın atak ve remisyon dönemlerinde ısı şok protein (HSP) 90 alfa ve vitamin düzeyindeki değişimleri sağlıklı gönüllülerle kıyaslamak ve bu moleküllerin AAA atağını kontrol etmede, amiloid birikimini önlemede faydasının olup olmayacağını araştırmak, ayrıca bu moleküllerin AAA gen mutasyonları ile ilişkilerinin araştırılması amaçlandı.

Hastalar ve Yöntem: Hastanemiz çocuk nefrolojisi bölümünde AAA tanılı 30 hastadan atak ve remisyon dönemlerinde ve 30 sağlıklı gönüllüden alınan kan örneklerinde HSP 90 alfa, A vitamini, B 12 vitamini, D vitamini, E vitamini ve folik asit düzeyleri çalışıldı ve sonuçlar birbirleriyle kıyaslandı.

Bulgular: Hastaların 19'u erkek, 11'i kızdı ve yas ortalaması 11 yıldı. HSP 90 alfa atak grubunda en yüksek, en düşük ise remisyon grubunda olmasına rağmen gruplar arasında anlamlı fark bulunmadı. B12 vitamini gruplar arasında anlamlı düzeyde farklıydı ve en yüksek değer kontrol grubundaydı. D vitamini atak ve remisyon grupları arasında anlamlı derecede farklıydı ve en yüksek değer atak grubunda idi. D vitamini düzeyi erkeklerde anlamlı yüksekti. A vitamini, E vitamini ve folik asit değerleri arasında anlamlı fark bulunmadı. AAA gen mutasyonlarının HSP 90 alfa ve vitamin düzeyleri üzerinde etkili olmadığı saptandı.

Sonuç: Bulgularımız AAA'da serum HSP 90 alfa, D vitamini, E vitamini ve folik asit değerlerinin normal olduğunu, ancak B12 vitamini ve A vitamini düzeylerinin atak ve remisyon sırasında düşük olduğunu göstermiştir.
\end{abstract}

Anahtar Kelimeler: Ailevi Akdeniz ateşi, vitamin, ısı şok protein 90 alfa, mutasyon, atak, remisyon

\section{Abstract}

Aim: It was aimed to compare with healthy volunteers the changes in heat shock protein (HSP) 90 alpha and vitamin levels during exacerbation and remission periods in our patients with familial Mediterranean fever (FMF), to research whether these molecules will benefit in control of FMF exacerbation and prevention of amyloid accumulation, and also to investigate the relationship of these molecules with FMF gene mutations.

Patients and Methods: HSP 90 alpha, vitamin A, vitamin B 12, vitamin D, vitamin E and folic acid levels were studied in 30 patients with AAA diagnosed in our hospital's pediatric nephrology department during the exacerbation and remission periods and 30 healthy volunteers and the results were compared. Results: Nineteen of the patients were male, 11 were female, with a mean age of 11 years. Although HSP 90 alpha was the highest in the exacerbation group and the lowest in the remission group, there was no significant difference between the groups. Vitamin B12 was significantly different between the groups and the highest value was in the control group. Vitamin $D$ was significantly different between the exacerbation and the remission groups and the highest value was in the exacerbation group. Vitamin $\mathrm{D}$ levels were significantly higher in boys. There was no significant difference between vitamin A, vitamin $E$ and folic acid levels. FMF gene mutations did not affect HSP 90 alpha and vitamin levels.

Conclusion: Our findings showed that serum HSP 90 alpha, vitamin D, vitamin E and folic acid levels were normal in AAA, but vitamin B12 and vitamin A levels were low during exacerbation and remission.

Key words: Familial Mediterranean fever, vitamin, heat shock protein 90 alpha, mutation, exacerbation, remission

Atıf yapmak için: Ataş B, Kutlu S. Çocukluk Çağı Ailevi Akdeniz Ateşi Hastalarında Isı Şok Protein 90 Alfa ve Vitamin Düzeylerindeki Değişim. Selcuk Med J 2021; 37(2): $146-150$

Açıklama: Yazarların hiçbiri, bu makalede bahsedilen herhangi bir ürün,
aygıt veya ilaç ile ilgili maddi çıkar ilişkisine sahip değildir. Araştırma,
herhangi bir dış organizasyon tarafından desteklenmedi. Yazarlar çalışmanın
birincil verilerine tam erişim izni vermek ve derginin talep ettiği takdirde
verileri incelemesine izin vermeyi kabul etmektedirler.




\section{GíRiş}

Periyodik ateş sendromlarından en sık görüleni olan ailevi Akdeniz ateşi (AAA), tekrarlayan ateş, peritonit, sinovit, plörit, perikardit gibi klinikle karakterize, otozomal resesif geçişli, en önemli komplikasyonu doku ve organlarda sekonder amiloidoz birikimi olan otoinflamatuar bir hastalıktır $(1,2)$. Hastalıkta ana bozukluğun interlökin-1 yolağında olduğu bulunmuştur (3). Meyve sineği olarak bilinen Drosofilaria melanogaster larvalarında ıSı şok cevabının ürünlerine "ISı şok protein" (HSP) ismi 1974 yılında verilmiştir (4). Stres proteinleri olarak da isimlendirilen HSP'ler, bütün canlı hücrelerinde bulunan bir grup proteindir. İnflamasyon, hipoksi gibi değişik stresler sonucunda HSP'lerin oluştuğu, yapımının arttığı saptanmıştır $(5,6)$. Molekül ağırlıklarına göre HSP-100, HSP-90, HSP-70, HSP-60 ve small HSP olarak 5 ana gruba ayrilır (7-9). Normal şartlarda, HSP'ler hücrede üretilen proteinlerin doğru bir şekilde katlanmasına, strese bağlı oluşan protein denatürasyonu ve agregasyonuna karşı bir savunma görevi yapmaktadır. Yani öncelikli görevi hücreyi korumaktır. Yanlış katlanma bozuklukları en çok ısı artışı ile oluşmaktadır (10). Başlıca protein bağlayıcı HSP'ler HSP 70 ve HSP 90'dır (11,12). HSP 90'ın sitozol içerisinde HSP 90 alfa ve HSP 90 beta olmak üzere iki izoformu vardır. HSP 90 beta daha fazla bulunur (9). Ancak HSP 90 alfanın çevresel, fiziksel ve kimyasal stres karşısındaki indüksiyonu, hücresel bütünlüğün korunması ve organizmanın hayatta kalması fonksiyonunda etkisi daha fazladır (13).

A vitamini $\% 90$ oranında karaciğerde depolanan bir antioksidandır (14). Yağda çözünen bir vitamin olan A vitamininin görme, büyüme ve gelişme, epitel hücre bütünlüğü, immün sistem ve üreme sisteminin düzgün çalışması üzerinde görevleri vardır (15). Ateşli sistemik infeksiyonlarda $A$ vitamininin üriner kaybı ve metabolik kullanımı artmaktadır (16). Suda eriyen bir vitamin olan B12 vitamininin en önemli fonksiyonu hücrelerin bölünmesi ve çoğalması için gerekli olan DNA yapımını sağlamaktır. İkinci önemli etkisi, santral sinir sistemi ve periferik sinir sistemindeki nöronların yapı ve fonksiyonlarını düzgün sürdürmelerini sağlamaktır (17). D vitaminin kemik metabolizmasına etkisinden başka bağışıklık sistemi üzerinde antiinflamatuar etkileri de vardır (18-21). E vitamini yağda çözünen, en güçlü antioksidan olan vitamindir (21). Folik asit ise özellikle DNA sentezi sırasında koenzim olarak görev alan bir vitamindir $(22,23)$.

Çalışmamızda AAA tanılı hastalarımızın atak ve remisyon dönemlerindeki HSP 90 alfa, A vitamini, B12 vitamini, D vitamini, E vitamini ve folik asit düzeyleri sağlıklı gönüllülerle kıyaslandı ve bu moleküllerin hastalığın takip ve tedavisinde faydasının olup olmayacağı araştırıldı.

\section{HASTALAR VE YÖNTEM}

Çalışmamız için atak, remisyon ve kontrol olarak üç grup oluşturuldu. Atak ve remisyon grubu aynı hastalardı. 2015 yılında, Necmettin Erbakan Üniversitesi Meram Tıp Fakültesi Çocuk Nefrolojisi bölümünde AAA tanılı 6 ay- 18 yaş arası 30 hastadan atak ve remisyon (atak geçtikten 15 gün sonra) dönemlerinde HSP 90 alfa, A vitamini, B12 vitamini, D vitamini, E vitamini ve folik asit düzeyleri çalışıldı. Her hasta çalışmaya bir kez alındı. Üçüncü grup olan kontrol grubu, çocuk sağlığı ve hastalıkları polikliniğine nonspesifik şikayetlerle başvuran, benzer yaş ve cinsiyette, gelişimleri normal, akut veya kronik bir hastalığı olmayan, herhangi bir ilaç ve vitamin kullanmayan 30 çocuktan oluşturuldu. Kontrol grubundaki çocuklardan gönüllülük esasına dayalı olarak kan alındı. Çalışılan bu parametreler gruplar arasında ve kendi aralarında karşılaştırıldı.

Çalışma için Etik Kurul Komisyonu tarafından 05.12.2014 tarih ve 2014/54 numaralı karar ile proje onaylandı. Hastalardan bilgilendirilmiş onay formu alındı. Alınan kan örneklerinin serumlarında HSP 90 alfa ve vitaminler, Enzyme Linked ImmunoSorbent Assay (ELISA) yöntemi ile çalışıldı. Çalışmanın tüm analizleri SPSS 20.0 paket programı ile yapıldı. İsimsel ölçekli (kategorik) değişkenler sıklık (frekans) ve yüzde oranı, oransal ölçekli (sayısal) değişkenler medyan (Q1-Q3) şeklinde tablo ve grafikler kullanılarak sunuldu. Grup karşılaştırmaları için tek yönlü varyans analizi ve anlamlı sonuçlar için Tukey HSD ikili karşılaştırma testleri kullanıldı. Parametrik şartların sağlanmadığı değişkenler için MannWhitney $U$ ve Kruskal-Wallis testleri tercih edildi. Tüm analizlerde $p<0,05$ değeri istatistiksel olarak anlamlı kabul edildi.

\section{BULGULAR}

Çalışmaya alınan AAA hastalarının 19'u (\%63,3) erkek, 11 'i $(\% 36,7)$ kızdı. Hastaların yaş ortalaması 11 yıldı. Kontrol grubunun ise 14'ü $(\% 46,7)$ erkek, 16'sı $(\% 53,3) \mathrm{kız}$, yaş ortalaması ise 8,5 yıldı. Hastaların atak döneminde en sık başvuru şikayeti ateşten sonra $19(\% 63,3)$ hastada karın ağrısı idi. Yalnızca yüksek ateş beş $(\% 16,7)$ hastada saptandı. Hastalarda en sık M694V mutasyonu tespit edilmiş olup $16(\% 46,7)$ hastada saptandı $(n=8 ; \% 26,7$ homozigot, $n=6 ; \% 20$ 
Tablo 1. Çalışma gruplarına göre yaş, HSP 90 alfa ve vitamin değerleri

\begin{tabular}{|c|c|c|c|c|}
\hline Özellikler & $\begin{array}{c}\text { Atak } \\
(n=30)\end{array}$ & $\begin{array}{c}\text { Remisyon } \\
(n=30) \\
\text { Medyan (Q1-Q3) }\end{array}$ & $\begin{array}{l}\text { Kontrol } \\
(n=30)\end{array}$ & $\mathbf{p}$ \\
\hline Yaş & 11 & 11 & 8,50 & \\
\hline$(\mathrm{Y} I \mathrm{l})$ & $(6,75-15)$ & $(6,75-15)$ & $(4-12,25)$ & 0,074 \\
\hline HSP 90 alfa & 55,05 & 37,60 & 46,55 & \\
\hline$(\mathrm{ng} / \mathrm{ml})$ & $(17,35-164,65)$ & $(9,85-151,2)$ & $(4,18-233,20)$ & 0,914 \\
\hline A vitamini & 443 & 360,50 & 592 & \\
\hline$(\mathrm{ng} / \mathrm{ml})$ & $(191,75-1564,50)$ & $(177-1343,50)$ & $(252-2445,75)$ & 0,114 \\
\hline \multirow[t]{2}{*}{ B12 vitamini (pmol/L) } & 432 & 311,50 & 619 & \\
\hline & $(259,25-1525)^{a}$ & $(178,25-1303,75)^{a, b}$ & $(225-2160)^{b}$ & 0,028 \\
\hline D vitamini & 12 & 9,55 & 8,65 & \\
\hline$(\mathrm{ng} / \mathrm{ml})$ & $(9-14,78)^{a}$ & $(4,93-13,20)^{a}$ & $(6,83-12,98)$ & 0,032 \\
\hline E vitamini & 120,15 & 82,95 & 101,95 & \\
\hline$(\mathrm{nmol} / \mathrm{ml})$ & $(39,53-354,20)$ & $(23,45-325,40)$ & $(11,28-500,33)$ & 0,913 \\
\hline Folik asit & 17,40 & 12,35 & 13,60 & \\
\hline$(\mathrm{nmol} / \mathrm{L})$ & $(7,83-39,83)$ & $(4,93-45)$ & $(5,48-64,08)$ & 0,472 \\
\hline
\end{tabular}

aAtak ile remisyon grubu arasında istatistiksel olarak anlamlı

${ }^{\mathrm{b} R e m i s y o n}$ ile kontrol grubu arasında istatistiksel olarak anlamlı

heterozigot). M680I dört (\%13.3), V726A iki (\%6.6), E148Q bir (\%3.3) hastada saptandı. Beş hastada $(\% 16,7)$ mutasyon yoktu. HSP 90 alfa en yüksek atak grubunda iken en düşük ise remisyon grubundaydı. Ancak gruplar arasında anlamlı fark bulunmadı (Tablo 1). A vitamini düzeyi de kontrol grubunda en yüksek ortalamaya sahipken en düşük remisyon grubundaydı. Ancak gruplar arasında anlamlı fark bulunmadı. B12 vitamini gruplar arasında anlamlı düzeyde farklıydı ve en yüksek değer kontrol grubundayken en düşük remisyon grubundaydı. D vitamini ise atak ve remisyon grubu arasında anlamlı düzeyde farklıydı ve remisyon grubunda daha düşüktü. Ayrıca $D$ vitamini düzeyi erkeklerde kızlara göre anlamlı yüksekti. E vitamini ve folik asit değeri en yüksek atak grubunda iken en düşük ise remisyon grubundaydı. Ancak gruplar arasında anlamlı fark bulunmadı (Tablo 1).
AAA gen mutasyon tiplerinin (hastalarda atak sırasında bakıldı) HSP 90 alfa ve vitamin düzeyleri üzerinde etkili olmadığı saptandı (Tablo 2). Ancak bu grupta vaka sayılarının ve dağılımın asimetrik olması kesin bir yorum yapılmasını zorlaştırmaktadır. Akut faz reaktanları ile mutasyon ilişkisinde sedimantasyon değerlerinin M694V heterozigot mutasyonunda en yüksek değere sahip olduğu görüldü. C-reaktif protein (CRP) değerlerinin ise E148Q mutasyonuna sahip hastalarda en yüksek, mutasyonu olmayan çocuklarda ise en düşük ortalamaya sahip olduğu görüldü. Sedimantasyon, CRP ve fibrinojen ortalamalarının tamamı erkek çocuklarda daha yüksekti. Sedimantasyon, CRP ve fibrinojen ortalamaları karın ağrısı olan hastalarda diğer gruplara göre daha yüksekti. Ancak bu sonuçlar da istatistiki olarak anlamlı değildi.

Tablo 2. Mutasyonlara göre hastaların yaş, HSP 90 alfa ve vitamin düzeyleri

\begin{tabular}{|c|c|c|c|c|c|c|c|c|}
\hline Özellikler & $\begin{array}{l}\text { M694V } \\
\text { homozigot } \\
(n=8)\end{array}$ & $\begin{array}{l}\text { M694V } \\
\text { heterozigot } \\
(n=6)\end{array}$ & $\begin{array}{l}\text { Mutasyon } \\
\text { yok } \\
(n=5)\end{array}$ & $\begin{array}{l}\text { V726A } \\
\text { heterozigot } \\
(n=2) \\
\text { Medyan (Q1-Q3) }\end{array}$ & $\begin{array}{l}\text { M680I } \\
\text { homozigot } \\
(n=3)\end{array}$ & $\begin{array}{l}\text { M680I } \\
\text { heterozigot } \\
(n=1)\end{array}$ & $\begin{array}{l}\text { E148Q } \\
\text { heterozigot } \\
(n=1)\end{array}$ & $\begin{array}{l}\text { İki farklı } \\
\text { mutasyon } \\
(n=4)\end{array}$ \\
\hline $\begin{array}{l}\text { Yaş } \\
\text { (YII) }\end{array}$ & $\begin{array}{l}12 \\
(7,75-15,75)\end{array}$ & $\begin{array}{l}10,50 \\
(4-15)\end{array}$ & $\begin{array}{l}8 \\
(7-11)\end{array}$ & $\begin{array}{l}13 \\
(11-15)\end{array}$ & $\begin{array}{l}16 \\
(11-17)\end{array}$ & 17 & 12 & $\begin{array}{l}10,50 \\
(4-15)\end{array}$ \\
\hline $\begin{array}{l}\text { HSP } 90 \text { alfa } \\
\text { (ng/ml) } \\
\text { A vitamini }\end{array}$ & $\begin{array}{l}11,45 \\
(4-145,62)\end{array}$ & $\begin{array}{l}31,35 \\
(13,92-91,07)\end{array}$ & $\begin{array}{l}155,25 \\
(14,95-194,15)\end{array}$ & $\begin{array}{l}169,70 \\
(134,40-216,85)\end{array}$ & $\begin{array}{l}30,2 \\
(7,20-141,90)\end{array}$ & 170,45 & 11,45 & $\begin{array}{c}31,35 \\
3,92-91,07)\end{array}$ \\
\hline$(\mathrm{ng} / \mathrm{ml})$ & $\begin{array}{l}244 \\
(124,50-1063,25)\end{array}$ & $\begin{array}{l}246,5 \\
(174-844)\end{array}$ & $\begin{array}{l}832,5 \\
(185,75-1626,25)\end{array}$ & $\begin{array}{l}1881,5 \\
(1150,75-2367)\end{array}$ & $\begin{array}{l}400 \\
(165-1841,75)\end{array}$ & 1819,50 & 244 & $\begin{array}{l}246,50 \\
(174-844)\end{array}$ \\
\hline $\begin{array}{l}\text { B12 } \\
\text { vitamini } \\
(\mathrm{pmol} / \mathrm{L})\end{array}$ & $\begin{array}{l}259,50 \\
(139,75-1329,75)\end{array}$ & $\begin{array}{l}356,5 \\
(228,50-734,25)\end{array}$ & $\begin{array}{l}455 \\
(230,50-1555,75)\end{array}$ & $\begin{array}{l}1741 \\
(1307,75-2373)\end{array}$ & $\begin{array}{l}304 \\
(256,5-1628)\end{array}$ & 1825,50 & 259,50 & $\begin{array}{c}356,50 \\
, 50-734,25)\end{array}$ \\
\hline $\begin{array}{l}\text { D vitamini } \\
(\mathrm{ng} / \mathrm{ml})\end{array}$ & $\begin{array}{l}9,75 \\
(5,70-12,57)\end{array}$ & $\begin{array}{l}13,05 \\
(10,15-18,40)\end{array}$ & $\begin{array}{l}11,3 \\
(7,67-14,17)\end{array}$ & $\begin{array}{l}8,3 \\
(3,72-11,75)\end{array}$ & $\begin{array}{l}7,45 \\
(1,25-15,30)\end{array}$ & 15,55 & 9,75 & $\begin{array}{l}13,05 \\
0,15-18,40)\end{array}$ \\
\hline $\begin{array}{l}\text { E vitamini } \\
(\mathrm{nmol} / \mathrm{ml})\end{array}$ & $\begin{array}{l}26,90 \\
(10,87-313,57)\end{array}$ & $\begin{array}{l}69,45 \\
(32,22-197,12)\end{array}$ & $\begin{array}{l}334,05 \\
(34,42-416,97)\end{array}$ & $\begin{array}{l}364,95 \\
(289,57-465,45)\end{array}$ & $\begin{array}{l}67,05 \\
(17,62-305,52)\end{array}$ & 366,45 & $(32$, & $\begin{array}{c}69,45 \\
, 22-197,12)\end{array}$ \\
\hline $\begin{array}{l}\text { Folik asit } \\
(\mathrm{nmol} / \mathrm{L})\end{array}$ & $\begin{array}{l}8 \\
(4,05-34,37)\end{array}$ & $\begin{array}{l}10,1 \\
(6,22-36,07)\end{array}$ & $\begin{array}{l}34,95 \\
(6,20-46,55)\end{array}$ & $\begin{array}{l}47,15 \\
(28,60-61,12)\end{array}$ & $\begin{array}{l}13,80 \\
(6,4-45,47)\end{array}$ & 43,20 & (6 & $\begin{array}{c}10,10 \\
6,22-36,07)\end{array}$ \\
\hline
\end{tabular}




\section{TARTIŞMA}

AAA uzun süreden beri bilinen, iyi tanımlanan otoinflamatuar bir hastalıktır. AAA ile ilgili pek çok çalışma yapılmasına rağmen literatürde AAA ile HSP 90 alfa ilişkisini gösteren bir çalışmaya rastlanmadı. Bizim çalışmamızda en yüksek HSP 90 alfa değeri kontrol grubunda, en düşük ise remisyon grubunda saptandı, ancak gruplar arasında anlamlı fark bulunmadı. Baykal et al. (24) bazı otoimmün ve inflamatuar hastalıklarda HSP'ye karşı otoantikor geliştiğini saptamışlardır. İnflamasyon, hipoksi gibi değişik stresler sonucunda HSP'lerin yapımının arttığı bilinmektedir. Bizim çalışmamızda ise HSP 90 alfa en yüksek atak döneminde saptanmış fakat sonrası remisyon döneminde azalma görülmüştür. $\mathrm{Bu}$ sonuç, atakta artan bu molekülün remisyon döneminde kullanımının veya tüketiminin devam ettiğini düşündürmüştür.

A vitamini düzeyi de kontrol grubunda en yüksek ortalamaya sahipken en düşük remisyon dönemindeydi. Ancak gruplar arasında anlamlı fark bulunmadı. Ateşli sistemik enfeksiyonlarda A vitamininin üriner kaybı ve metabolik kullanımının arttığı saptanmıştır (16). Bizim sonucumuz bu durumla uyumluydu ve remisyon dönemine kadar devem eden düşüş saptandı. B12 vitamini gruplar arasında anlamlı düzeyde farklıydı. Kontrol grubunda en yüksek ortalamaya sahipken en düşük düzeyi remisyon grubunda görüldü. Bazı çalışmalarda, özellikle kolşisin kullanan hastalarda B12 vitamin eksikliği görüldüğü belirtilmiştir. İleal mukoza hasarına bağlı olarak kolşisinin B12 vitamininin emilimini engellediğini Stopa et al. (25) ortaya koymuştur. Yılmaz et al. (26) uzun süreli kolşisin kullanan AAA hastalarında B12 vitamininin düşük olduğunu tespit etmişlerdir. Gemici et al. (27) ise 95 AAA hastası ile yapmış oldukları bir çalışmada ise aksine anlamlı bir fark tespit etmemişlerdir. Bu konuda çocuklarda yapılmış geniş hasta serili bir çalışma bulunmamaktadır. Bizim sonucumuzda, diğer vitaminlerde de benzer bir seyir görüldüğünden bu durum sadece kolşisin kullanımı ile ilişkilendirilememiştir. Başka faktörler de bunu etkilemiş olabilir. Literatürde AAA hastalarının atak ve remisyon dönemlerinde B12 vitamini düzeyini kıyaslayan çalışmaya rastlanmamıştır.

D vitamini düzeyleri atak ve remisyon grubu arasında anlamlı düzeyde farklıydı ve atak grubunda daha yüksekti. Kontrol grubunda en düşük ortalamaya sahip olmasına rağmen anlamlı değildi. Erten et al. (28) ve Kisacik et al. (29) AAA hastalarında D vitamini düzeyini normal popülasyona göre daha düşük bulmuşlardır. Çalışmamızda ise AAA hastalarında D vitamini düzeylerianlamlı olmasa da kontrol grubundan daha yüksekti. D vitaminin bağışıklık sistemi üzerinde antiinflamatuar etkilerinin olduğu bilinmekte olup, çalışmamızda inflamasyon sırasında arttığı ve atak sonrası azalmaya geçtiği görülmektedir. Genel olarak erkek çocuklarda kız çocuklarına göre $D$ vitamini düzeyi daha yüksek bulunmuştur $(E / K=11,50$ (8,3515,82 / 8,30 (5,40-11,95 ng/ml. p;0,002). E vitamini yağda çözünen, en güçlü antioksidan vitamindir (21). Folik asit ise özellikle DNA sentezi sırasında koenzim olarak görev almaktadır $(22,23)$. E vitamini ve folik asit değerleri en yüksek kontrol grubunda saptanırken en düşük remisyon grubundaydı. Ancak gruplar arasında anlamlı fark bulunmadı. Literatürde AAA hastalarında vitamin düzeyleri arasındaki değişimi gösteren çalışmaya rastlanmadı.

Çalışmış olduğumuz tüm parametrelerin düzeyleri atak döneminde remisyon dönemine göre daha yüksek saptandı. Ancak remisyon döneminde kliniğin düzelmesine ve akut faz yanıtının normale gelmesine rağmen HSP 90 alfa ve vitamin seviyelerinin daha düşük seyretmesi hücresel düzeyde inflamasyonun hala devam ettiği şüphesini veya inflamasyonla düşmeye başlayan bu moleküllerin henüz toparlanamadığını ve kullanımlarının hala devam ettiğini düşündürmektedir. Bu durumu açıklamak için daha geniş serili çalışmalara intiyaç vardır. AAA gen mutasyonları tipinin HSP 90 alfa ve vitamin düzeyleri üzerinde etkili olmadığı saptandı. Literatürde mutasyonlarla HSP 90 alfa ve vitamin düzeyleri arasındaki değişimi gösteren çalışmaya rastlanmadı. Çalışmamızda akut faz reaktanları ile mutasyon ilişkisine bakıldığında sedimantasyon değerlerinin M694V heterozigot mutasyonunda en yüksek, E148Q mutasyonunda ise en düşük değere sahip olduğu tespit edildi. CRP değerlerinin ise $\mathrm{E} 148 \mathrm{Q}$ mutasyonuna sahip hastalarda en yüksek, mutasyonu olmayan çocuklarda ise en düşük ortalamaya sahip olduğu görüldü. Literatürde akut fazlarla mutasyonlar arasındaki ilişkiyi gösteren çalışmaya rastlanmadı. Bu sonuçlar ilgi çekici bulundu. Hasta sayısının az olması ve HSP'lerin diğer subgruplarının çalışılamaması çalışmamızı kısıtlayan durumlardır.

Sonuç olarak, ülkemiz gibi taşıyıcı sıklığının ve hastalık prevalansının yüksek olduğu toplumlarda AAA hala ciddiyetini korumaktadır. Bu nedenle farklı parametrelerin araştırılması, hastalığın takip, tedavi ve komplikasyonların önlenmesi açısından değerli olabilir. 
Üniversitemiz Bilimsel Araştırma Projeleri Koordinatörlüğü tarafından 141518020 numaralı proje olarak desteklendi.

Çıkar Çatışması: Çalışmada herhangi bir çıkar çatışması yoktur.

Finansal Çıkar Çatışması: Çalışmada herhangi bir finansal çıkar çatışması yoktur.

Yazışma Adresi: Bülent Ataş, Necmettin Erbakan Üniversitesi, Meram Tıp Fakültesi, Çocuk Sağlığı ve Hastalıkları Anabilim Dalı, Çocuk Nefrolojisi Bilim Dalı, Konya,42090 Türkiye

e-mail: bulentatas@hotmail.com

\section{KAYNAKLAR}

1. Hoffman H, Patel D. Genomic-based therapy: Targeting interleukin-for autoinflammatory diseases. Arthritis Rheum 2004;50:345-9.

2. Sohar E, Gafni J, Pras M, et al. Familial mediterranean fever. A survey of 470 cases and review of the literature. Am J Med 1967;43:227-53.

3. Kasapçopur Ö, Barut K, Şahin S, et al. Çocukluk çağında otoenflamatuar hastalıklar, Cerrahpaşa Tıp Fakültesi Yayınları, İstanbul 2016;1-15.

4. Tissieres A, Mitchell HK, Tracy UM. Protein synthesis in salivary glands of drosophila melanogaster: Relation to chromosome puffs. J Mol Biol 1974;84:389-98.

5. Milani V, Noessner E, Ghose S, et al. Heat shock protein 70: Role in antigen presentation and immune stimulation. Int $\mathrm{J}$ Hyperthermia 2002;18:563-75.

6. Rylander MN, Feng Y, Bass J, et al. Thermally induced injury and heat-shock protein expression in cells and tissues. Ann N Y Acad Sci 2005;1066:222-42.

7. Easton DP, Kaneko Y, Subjeck JR. The hsp110 and Grp1 70 stress proteins: Newly recognized relatives of the Hsp70s. Cell Stress Chaperones 2000;5:276-90.

8. Tang D, Khaleque A, Jones EL, et al. Expression of heat shock proteins and HSP messenger ribonucleic acid in human prostate carcinoma in vitro and in tumors in vivo. Cell Stress Chaperones 2005;10:46-58.

9. Banerji U. Heat shock protein 90 as a drug target: Some like it hot. Clin Cancer Res 2009;15:9-14.

10. Öztürk $E$, Kahveci N, Özlük K, et al. Heat shock proteins. Ulusal Cerrahi Dergisi 2009;25:131-6.

11. Wegele H, Müller L, Buchner J. Hsp70 and Hsp90-a relay team for protein folding. Rev Physiol Biochem Pharmacol 2004;151:1-44.

12. Mayer MP, Bukau B. Hsp70 chaperones: Cellular functions and molecular mechanism. Cell Mol Life Sci 2005;62:670-84.

13. Islam $A$, Rehana $B$, Zhang $M$, et al. Expression of heat shock protein 90 alpha (Hsp90a) in primary neonatal rat myocardial cells exposed to various periods of heat stress in vitro. Genet Mol Res 2014;13:2806-16.

14. Pryor WA, Stahl W, Rock CL. Beta carotene: From biochemistry to clinical trials. Nutr Rev 2000;58:39-53.

15. McLaren DS, Frigg M. Sight and life manual on vitamin A deficiency disorders. Task Force Sight and Life, Switzerland, 1997.

16. Stephensen CB, Alvarez JO, Kohatsu J, et al. Vitamin A is excreted in the urine during acute infection. Am $\mathrm{J}$ Clin Nutr 1994;60:388-92.

17. Kayaalp SO. Tıbbi Farmakoloji, Cilt 2, 8. Baskı, Hacettepe Taş Kitabevi, Ankara, 1998:1580-8.

18. Adams JS, Sharma OP, Gacad MA, et al. Metabolism of 25-hydroxyvitamin D3 by cultured pulmonary alveolar macrophages in sarcoidosis. J Clin Invest 1983;72:1856-60.

19. Bikle D. Nonclassic actions of vitamin D. J Clin Endocrinol Metab 2009;94:26-34.

20. Autier P, Gandini S. Vitamin D supplementation and total mortality: A meta-analysis of randomized controlled trials. Arch Intern Med 2007;10;167:1730-7.

21. Kayaalp SO. Tıbbi Farmakoloji, Cilt 2, 9. Baskı Hacettepe Taş Kitabevi, Ankara, 2000:1541-75.

22. Coşkun T. Folik asit. Hacettepe Üniversitesi Katkı Dergisi 2003;25:489-98.

23. Laird PW. Cancer epigenetics. Hum Mol Genet 2005;14:6576.

24. Baykal Y, Gök F, Kocabalkan F. Heat shock proteins and their role in diseases. T Klin J Med Sci 2000;20:187-95.

25. Stopa EG, O'Brien R, Katz M. Effect of colchicine on guine pig intrinsic factor-vitamin B12 receptor. Gastroenterology 1979;76:309-14.

26. Yilmaz R, Ozer S, Ozyurt H, et al. Serum vitamin B12 status in children with familial Mediterranean fever receiving colchicine treatment. Hong Kong J Paediatr 2011;16:3-8.

27. Gemici Al, Sevindik ÖG, Akar S, et al. Vitamin B12 levels in familial Mediterranean fever patients treated with colchicine. Clin Exp Rheumatol 2013;31:57-9.

28. Erten S, Erten F, Altunoglu A. Successful treatment with anti-tumor necrosis factor (anti-TNF)-alpha of proteinuria in a patient with familial mediterranean fever (FMF) resistant to colchicine: Anti-TNF drugs and FMF. Rheumatol Int 2012;32:1095-7.

29. Kisacik B, Kaya SU, Pehlivan Y, et al. Decreased vitamin $D$ levels in patients with familial mediterranean fever. Rheumatol Int 2013;33:1355-7. 